\title{
Levels and trends of industrial chemicals (PCBs, PFCs, PBDEs) in archived herring gull eggs from German coastal regions
}

\author{
Annette Fliedner ${ }^{1 *}$, Heinz Rüdel ${ }^{1}$, Heinrich Jürling ${ }^{1}$, Josef Müller ${ }^{1}$, Frank Neugebauer ${ }^{2}$ and \\ Christa Schröter-Kermani ${ }^{3}$
}

\begin{abstract}
Background: Polychlorinated biphenyls [PCBs], perfluorinated compounds, and polybrominated diphenyl ethers [PBDEs] were retrospectively analyzed in archived herring gull (Larus argentatus) eggs from the North and the Baltic Sea over the last 20 years. The aim was to assess temporal trends and effects of regulatory measures.

Results: PCBs (sum of 7 congeners) were highest in eggs from the North Sea island Trischen, i.e., 3,710 to 20,760 ng/g lipid weight [lw] compared to 2,530 to 11,650 ng/g Iw on the North Sea island Mellum and 4,840 to 9,190 ng/g Iw on the Baltic Sea island Heuwiese. During the study period, PCBs decreased significantly. Concentrations of PFOS ranged between 46 and $170 \mathrm{ng} / \mathrm{g}$ wet weight [ww] at Trischen, 39 to $99 \mathrm{ng} / \mathrm{g}$ ww at Mellum, and 20 to $159 \mathrm{ng} / \mathrm{g} \mathrm{ww}$ at Heuwiese. Since 2000 and 2003, concentration levels decreased in eggs from Mellum and Heuwiese, respectively. Perfluorooctanoic acid was the dominant perfluorinated carboxylic acid in the North Sea eggs (Trischen 2.0 to $74 \mathrm{ng} / \mathrm{g}$ ww; Mellum 2.6 to $118 \mathrm{ng} / \mathrm{g}$ ww), whereas perfluoroundecanoate [PFUnA] and perfluorodecanoate [PFDA] (means $3.9 \pm 3.6 \mathrm{ng} / \mathrm{g}$ and $2.9 \pm 2.3 \mathrm{ng} / \mathrm{g} \mathrm{ww}$, respectively) dominated in the Baltic Sea eggs. At all three locations, longerchained perfluorinated carboxylic acids (perfluorononanoate, PFDA, PFUnA, perfluorododecanoate) increased during the monitoring period. PBDE concentrations (sum of 35 congeners) in eggs were in the ranges of 282 to 2,059 $\mathrm{ng} / \mathrm{g} \mathrm{lW}$ (Mellum), 116 to 1,722 ng/g (Trischen), and 232 to 2,021 ng/g Iw (Heuwiese). Congeners associated with commercial Penta- and Octa-BDE formulations decreased during the study period. No decrease was observed for technical Deca-BDE.
\end{abstract}

Conclusion: Effects of regulatory measures were apparent for PCBs and Penta- and Octa-BDE, while no consistent trend is noticeable for PFOS.

Keywords: Environmental Specimen Bank, PCB, PFC, PBDE, herring gull eggs, North Sea, Baltic Sea

\section{Background}

Industrial chemicals like polychlorinated biphenyls $[\mathrm{PCBs}]$, perfluorinated compounds [PFCs], and polybrominated diphenyl ethers [PBDEs] have been used in innumerable applications for many years. In recent years, however, it became clear that these compounds are by no means unproblematic when reaching the environment. Many of them are highly persistent, bioaccumulative and toxic. Furthermore, the substances themselves or their

\footnotetext{
* Correspondence: annette.fliedner@ime.fraunhofer.de

'Fraunhofer Institute for Molecular Biology and Applied Ecology (Fraunhofer IME), Schmallenberg 57377, Germany

Full list of author information is available at the end of the article
}

precursors are subject to long-range transport and have been detected in biota in remote areas like the Arctic and Antarctica (e.g., [1-16]). These findings led to the inclusion of PCBs, certain PBDEs (i.e., hexabromodiphenyl ether, heptabromodiphenyl ether, tetrabromodiphenyl ether, and pentabromo-diphenyl ether), as well as the PFCs' perfluorooctane sulfonic acid [PFOS] and its salts and perfluorooctane sulfonyl fluoride into the list of persistent organic pollutants [POPs] covered by the Stockholm Convention on POPs [17,18]. Already 9 years earlier, in 2000, a voluntary phase-out of PFOS was initiated by its main producer $3 \mathrm{M}$. Others, like perfluorooctanoic acid [PFOA] are still under evaluation. In the

\section{Springer}

(c) 2012 Fliedner et al; licensee Springer. This is an Open Access article distributed under the terms of the Creative Commons Attribution License (http://creativecommons.org/licenses/by/2.0), which permits unrestricted use, distribution, and reproduction in any medium, provided the original work is properly cited. 
European Union [EU], PCBs and technical Penta- and Octa-BDEs were banned already in 1985 and 2004, respectively $[19,20]$. An EU-wide restriction of Deca-BDE followed in 2008 (curia.europa.eu; case C-14/06).

Polychlorinated biphenyls were widely used since the late 1920 s, e.g., as hydraulic fluids, lubricating oils, and cooling and insulating fluids for transformers and capacitors, plasticizers, stabilizing additives, and flame retardants. Their unfavorable properties, namely, persistence, lipophilicity, potential for bioaccumulation and biomagnification, and high chronic toxicity, were recognized already in the 1930s. Some of the 209 PCB congeners are even suspected to be carcinogenic, teratogenic, reproductively and developmentally toxic, and endocrine-disruptive. Due to their lipophilicity, PCBs accumulate in fatty tissues and are sequestered into bird eggs [21-23].

Perfluorinated compounds have been used since the 1950s. Their chemical properties (e.g., heat resistance, lipophobicity, hydrophobicity) render them suitable for many applications, including fire-fighting foams, carpet impregnation, coatings and additives, leather and textile treatments, paper and packaging, industrial and household cleaning products, pesticides, and insecticides $[11,24]$. It was only in recent years that their environmental relevance became obvious [2]. Several PFCs are highly persistent, bioaccumulative and toxic and enrich in the food web [11,13,25-32]. Unlike lipophilic compounds like PCBs and PBDEs, PFCs bind to proteins, and concentrations are highest in the protein fraction of the blood, liver, and kidney [32-37]. For birds, a species- and compound-specific sequestering of PFCs into eggs can be observed [12,36-41].

Polybrominated diphenyl ethers are additive flame retardants which have been used for more than 30 years in multiple applications, such as polymers, paints, electrical appliances, and polyurethane foams used in furniture and cars [42,43]. Of 209 possible congeners, only about 20 to 30 are environmentally relevant as components or degradation products of the commercial formulations Penta-BDE, Octa-BDE, and Deca-BDE [42]. PBDEs are persistent, hydrophobic, bioaccumulative, and toxic. Some congeners act as endocrine disruptors, and the main component of technical Deca-BDE, BDE-209, has been classified as a possible human carcinogen [44-46]. Like PCBs, PBDEs accumulate in fatty tissues. They biomagnify in the food chain and are effectively transferred into bird eggs [43,47-49].

The dynamics of these substances in the environment and the effectiveness of regulatory measures can be evaluated by assessing temporal trends in biota. In this context, the German Environmental Specimen Bank [ESB] (http:// www.umweltprobenbank.de) [50-53] offers the opportunity for retrospective monitoring using archived specimens of marine, fresh water, and terrestrial ecosystems sampled regularly since the 1980s. Within the ESB, eggs of the herring gull (Larus argentatus) are used as specimen representing marine top predators [53]. These samples are of special interest when dealing with bioaccumulating and biomagnifying compounds.

The aim of the present study was to evaluate temporal trends of PCBs, PFCs, and PBDEs in herring gull eggs from islands in the North Sea and the Baltic Sea. It complements an earlier study dealing with PFCs in aquatic organisms and bird eggs [54]. For this purpose, archived homogenate samples from the German ESB covering the periods from 1988 to 2008 (North Sea) and $1991 / 1996$ to 2008 (Baltic Sea) were analyzed for PCBs (7 congeners), PBDEs (35 congeners), and PFCs (twelve individual compounds).

\section{Materials and methods \\ ESB sample treatment}

In order to ensure a high degree of continuity, all steps of the ESB sample treatment are performed according to ESB standard operation procedures $[50,55,56]$. Herring gull eggs are collected annually from the North Sea islands Trischen and Mellum and from the Baltic Sea island Heuwiese (Figure 1). Sampling is performed by trained personnel to minimize the disturbance of the colony. A detailed description of the sampling procedure is given in the corresponding standard operating procedure which can be retrieved from the website of the ESB (http://www.umweltprobenbank.de). Every year, at least 35 eggs from each site are pooled and homogenized. For this study, a total of 87 egg homogenates were analyzed. In general, samples were analyzed once. For determining the analytical precision, representative samples were analyzed as replicates.

\section{Analytical methods \\ $P C B$}

The analysis of herring gull eggs was performed by high-resolution gas chromatography/high-resolution mass spectrometry [HRGC/HRMS] using isotope dilution quantification. The method followed the mutually agreed procedure of the ESB [50] and the laboratory. Details of the analytical method and instrumentation are given in Additional file 1.

Standards and reagents The seven indicator PCB congeners IUPAC No. 28, 52, 101, 118, 138, 153, and 180 were investigated. The native standards were obtained from LGC Promochem, Wesel, Germany (Pesticide-Mixture No. 41), and the respective internal ${ }^{13} \mathrm{C}_{12}$-labeled standards were delivered by Cambridge Isotope Laboratories via LGC Promochem. Solvents were delivered by Merck, Darmstadt, Germany (n-pentane); LGC Promochem (cyclohexane, hexane, dichloromethane); and Mallinckrodt Baker, Griesheim, Germany (diethyl ether, ethanol, 


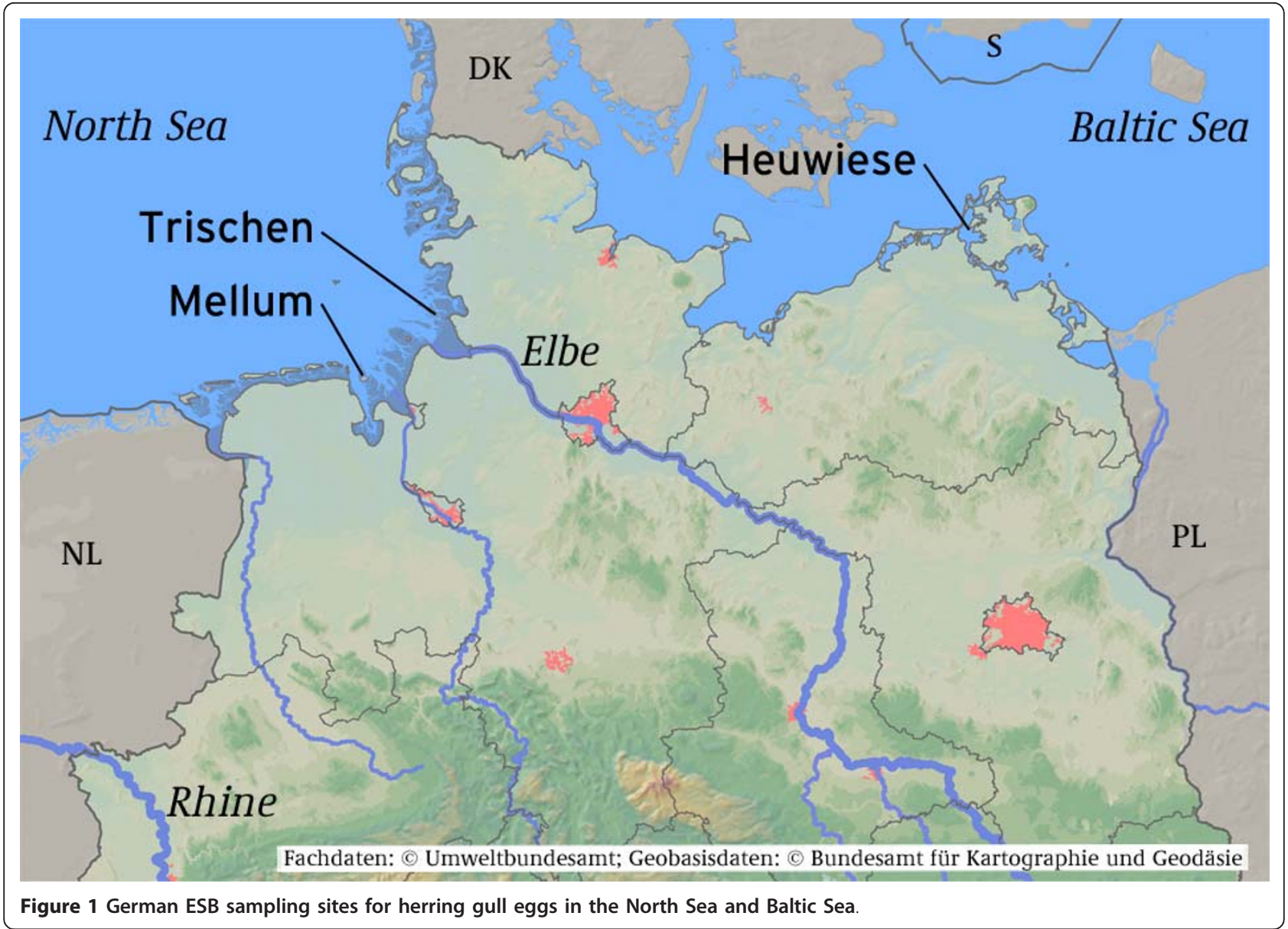

toluene). Silica gel, alumina oxide, sodium sulfate, and potassium oxalate were obtained from Merck.

Quality assurance measures A number of internal and external quality assurance/quality control $[\mathrm{QA} / \mathrm{QC}]$ procedures were performed: For each batch of 8 to 10 samples, a QC control sample and a blank sample were analyzed in parallel. Additionally, a number of samples were analyzed in duplicate. Regarding external controls, the laboratory participated in at least two international interlaboratory control studies per year for PCBs in biological samples. The successful participation in the Norwegian Institute of Public Health ring tests (Round 11, 2010; Round 12, 2011) and Quality Assurance of Information for Marine Environmental Monitoring in Europe [QUASIMEME] (Round 62, 2010 ) resulted in single analyte $z$-scores of $<2$ in $95 \%$ of the cases $(n=91)$.

PFC

Analysis of herring gull eggs was performed by high performance liquid chromatography-mass spectrometrymass spectrometry [HPLC-MS-MS] after fat removal by $n$-hexane extraction of alkaline sample suspensions followed by analyte extraction from the remaining and acidified aqueous phases using methyl tert-butyl ether [MTBE]. Details on the sample preparation, analytical methods, instruments, and quality assurance measures are given in Additional file 1.

Standards and reagents Seven perfluoroalkyl carboxylic acids (carbon chain lengths from $\mathrm{C} 4$ to $\mathrm{C} 12$ ) and five perfluoroalkyl sulfonic acids (carbon chain lengths C4, C6, C7, $\mathrm{C} 8$, and $\mathrm{C} 10$ ) were investigated: perfluorobutanoate [PFBA], perfluorohexanoate [PFHxA], PFOA, perfluorononanoate [PFNA], perfluorodecanoate [PFDA], perfluoroundecanoate [PFUnA], perfluorododecanoate [PFDoA], perfluorobutanesulfonate [PFBS], perfluorohexanesulfonate $[\mathrm{PFHxS}]$, perfluoroheptanesulfonate [PFHpS], PFOS, and perfluorodecanesulfonate [PFDS]. For nine PFCs, isotopically labeled compounds were used as internal standards (not available for PFBS, PFDS, and PFHpS). Analytes as well as the mass-labeled standards were from Wellington Laboratories (Guelph, Canada) and were obtained from Campro Scientific (Berlin, Germany) as solutions in methanol and methanol-water $(96+4, v / v)$, respectively. HPLCgrade methanol was purchased from Mallinckrodt Baker; ammonium acetate $(98 \%$, p.a.) from Fluka/Sigma-Aldrich 
Corporation, Steinheim, Germany; MTBE (p.a.), ammonium hydroxide $(25 \%)$, and hydrochloric acid $(37 \%$, p.a.) from Merck. Bidistilled water $(12 \mathrm{M} \Omega \cdot \mathrm{cm})$ was used for the preparation of reagent solutions and HPLC solvents.

Validation and quality assurance measures of analytical method The validation of the analytical method was performed by standard addition experiments. This was because no PFC-free egg matrix was available. The recoveries of the analytes were determined by means of the slope of the recovery functions. The respective mean recoveries for eight different concentration levels were the following: PFBA 74\%, PFBS 112\%, PFHxA 108\%, PFHxS 106\%, PFHpS 103\%, PFOA 95\%, PFNA 99\%, PFOS 95\%, PFDA 100\%, PFUnA 101\%, PFDS 76\%, and PFDoA $112 \%$. Reported data were not corrected for recoveries. In addition the parameters specificity, linearity, working range, accuracy, precision, and limit of quantitation [LOQ] were considered. The respective data are summarized in Additional file 1.

\section{PBDE}

PBDE were determined by HRGC/HRMS using isotope dilution quantification. The method followed the mutually agreed procedure of the ESB [50] and the laboratory. Details of the analytical method and instrumentation are included in Additional file 1.

Standards and reagents Native standards (BDE congeners $17,25,28,35,37,47,49,66,77,85,99,100,119$, $126,138,140,153,154,155,181,183,190,203,207)$ were obtained from Cambridge Isotope Laboratories via LGC Promochem, from Wellington Laboratories via Campro Scientific (BDE congeners 71, 156, 197, 209), and from AccuStandard via amchro $\mathrm{GmbH}$, Hattersheim, Germany (BDE congeners 75,116$)$. Seven internal ${ }^{13} \mathrm{C}_{12}$-labeled standards - BDE congeners 28, 47, 99, 153, 154, 183 and 209 - were delivered by Wellington Laboratories; one BDE 100 - was from Cambridge Isotope Laboratories. Solvents were delivered by Merck ( $n$-pentane), LGC Promochem (cyclohexane, hexane, dichloromethane), and Mallinckrodt Baker (diethyl ether, ethanol, toluene). Silica gel, alumina oxide, sodium sulfate, and potassium oxalate were obtained from Merck.

Quality assurance measures A number of internal and external QA/QC procedures were performed: For each batch of 6 to 10 samples, a QC control pool sample and a blank sample were analyzed in parallel. Additionally, a number of samples were analyzed in duplicate. Regarding external controls, the laboratory participated successfully in at least two international interlaboratory control studies per year for PBDEs in biological samples. The successful participation in the Norwegian Institute of Public Health ring tests (Round 11, 2010; Round 12, 2011) and QUASIMEME (Round 62, 2010) resulted in single analyte $z$-scores of $<2$ in $88 \%$ of the cases $(n=84)$.

\section{Statistics}

Time trends were analyzed using a statistical program (PIA) retrieved from the Arctic Monitoring and Assessment Programme homepage [57]. The program uses a robust regression-based analysis to assess time series [58]. The percent-annual concentration change is derived from the slope of a log-linear regression curve. The trend analysis was based on the curves of the mean concentrations per year and was performed for the whole study period as well as for certain periods which obviously displayed trends. The results and relevant statistical parameters are summarized in Table S7 in Additional file 1 .

\section{Results and discussion}

During the whole monitoring period, concentrations of PCBs were clearly higher than levels of PFCs and PBDEs in herring gull eggs from all three locations. Nevertheless, as Figure 2 shows exemplarily for three time spans, the relative importance of PCBs has declined significantly since the study began, while PFCs are steadily increasing at two locations (North Sea/Trischen and Baltic Sea/Heuwiese). Concentrations of PBDEs were mostly lower than those of PFCs and decreased during the monitoring period.

\section{PCB}

PCB contamination was highest in herring gull eggs from the North Sea island Trischen. During the study period from 1988 to 2008, the total PCB levels (sum of 7 congeners) ranged between 3,710 and $20,760 \mathrm{ng} / \mathrm{g}$ lipid weight [lw] (corresponding to 380 to $1,760 \mathrm{ng} / \mathrm{g}$ wet weight $[w w])$ with the highest concentrations between 1988 and 1992 (Figure 3) [see Table S4 in Additional file 1]. Eggs from Mellum had somewhat lower levels ranging between 2,530 and 11,650 ng/g lw (230 to $1,008 \mathrm{ng} / \mathrm{g} \mathrm{ww}$ ). Again, contaminations were highest in the late 1980s. At both North Sea sites, egg concentrations decreased significantly $(p<0.001)$ during the study period which is probably related to the EUwide ban of PCBs in 1985 [see Table S7 in Additional file 1]. At the Baltic Sea location Heuwiese, PCB analysis started in 1996. Total PCB concentrations ranged between 4,840 and 9,190 ng/g lw (corresponding to 460 and $900 \mathrm{ng} / \mathrm{g} \mathrm{ww}$ ) and decreased significantly ( $p<$ 0.038 ) during the whole study period. (Figure 3) [see Tables S4 and S7 in Additional file 1].

Congener patterns were similar at all three locations with CB-153 > CB-138 > CB-180 > CB-118 [see Table S4 in Additional file 1]. Lower chlorinated congeners, i.e., CB-28, -53 , and -101 accounted for only $0.2 \%$ to $6 \%$ of the total PCBs. These findings reflect the enhanced bioaccumulation potential of higher chlorinated PCBs - especially 


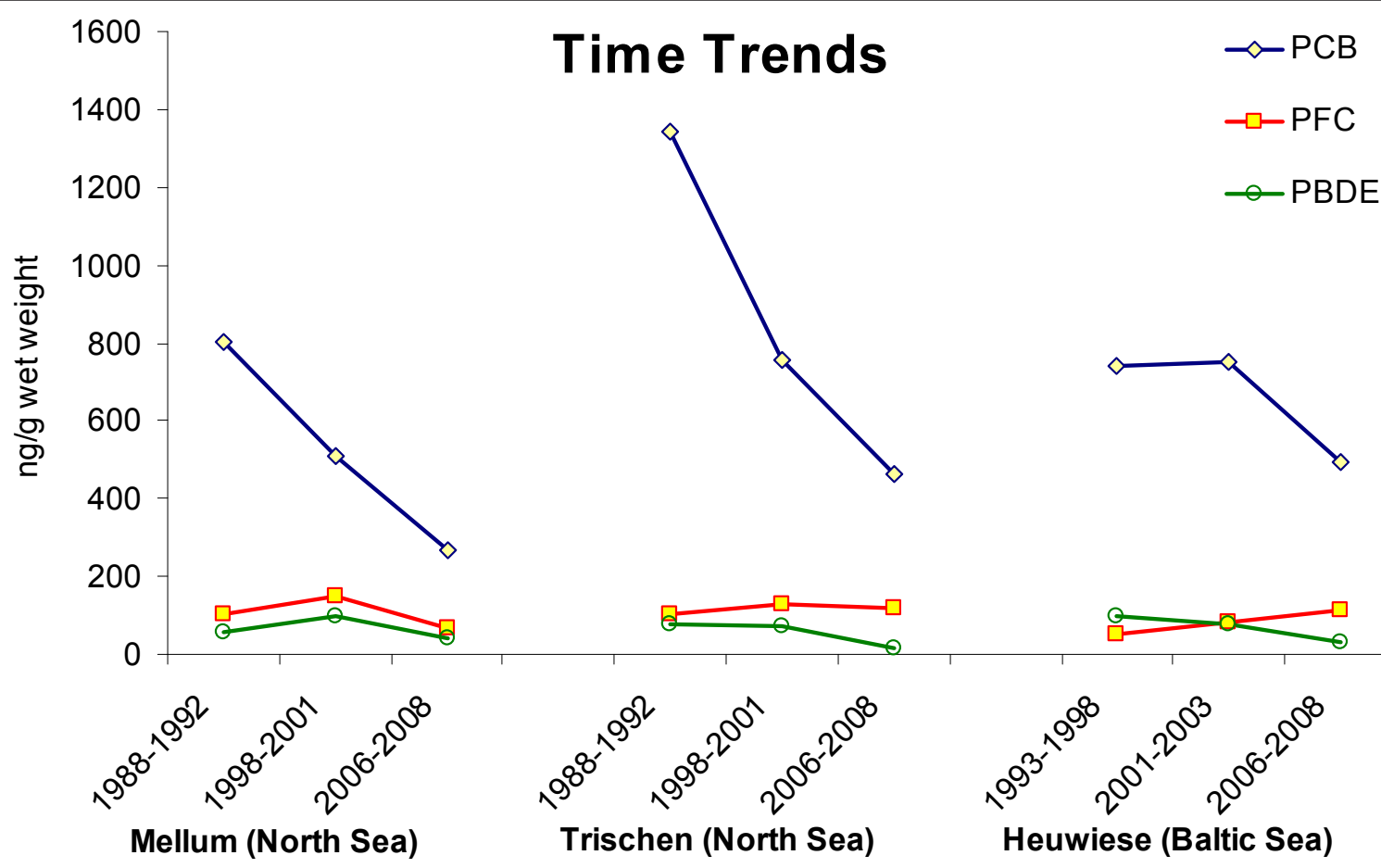

Figure 2 PCBs, PFCs, and PBDEs in herring gull eggs from three ESB locations in German coastal waters. Given are the mean concentrations of PCB (sum of congeners 28, 52, 101, 118, 138, 153, 180), seven PFCs (sum of PFOA, PFNA, PFDA, PFUnA, PFHxS, PFHpS, PFOS), and PBDE (sum of 35 congeners 1, 2, 3, 7, 10, 13, 15, 17, 25, 28, 35, 47, 49, 66, 71, 75, 77, 85, 99, 100, 116, 119, 126, 138, 140, 153, 154, 155, 156, $181,183,197,203,207,209)$. For values below the detection limit, a default value of 0.5 of the respective detection limit was included. 1988 to 1992: mean concentrations of the years 1988, 1990, and 1992; 1998 to 2001: mean concentrations of the years 1998, 2000, and 2001; 2006 to 2008: mean concentrations of the years 2006, 2007, and 2008; 1993 to 1998: mean concentrations of the years 1993, 1996, and 1998; 2001 to 2003: mean concentration of the years 2001, 2002, and 2003.

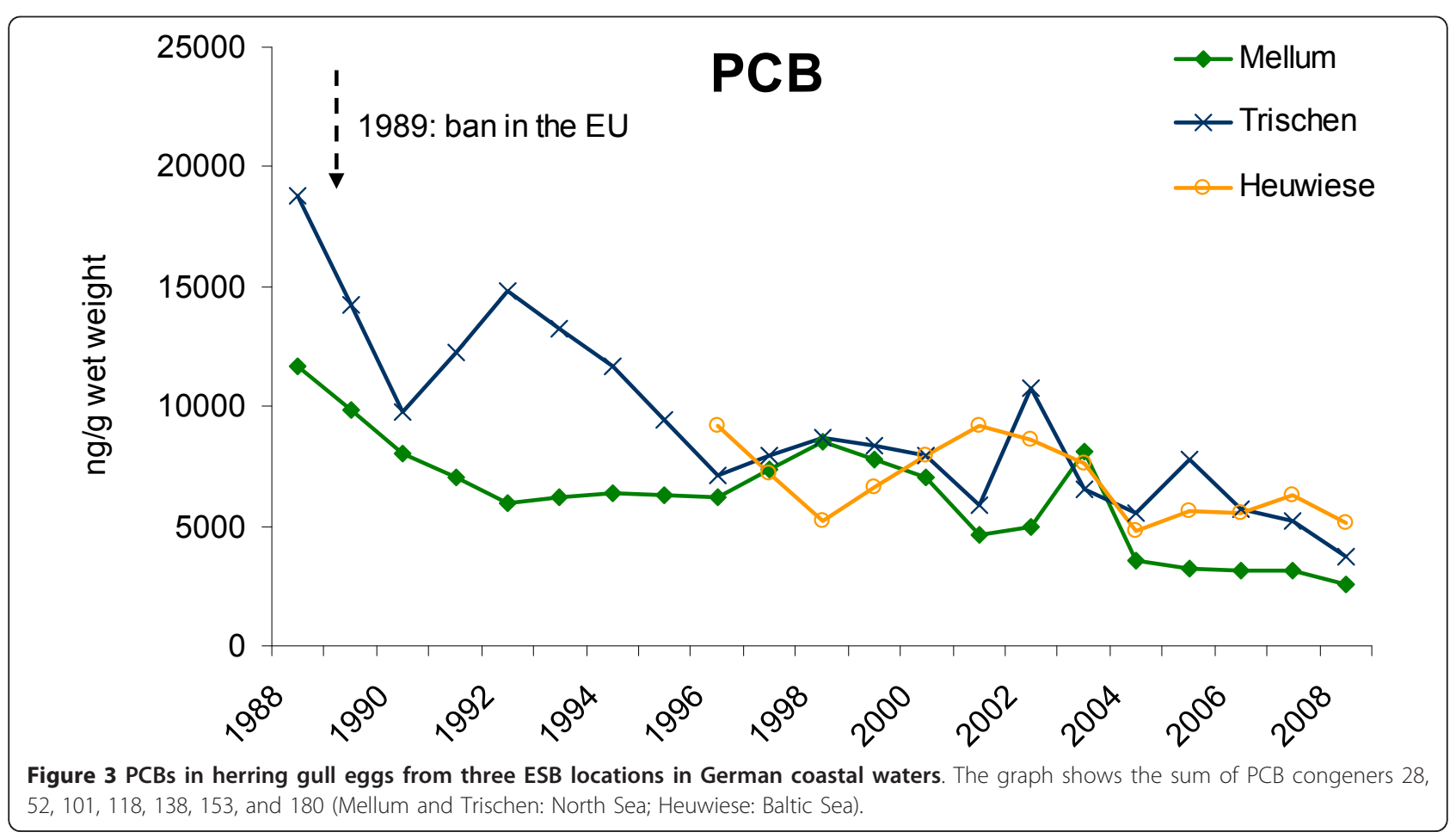


the hexachlorinated congeners CB-153 and CB-138 - as compared to the more volatile lower chlorinated congeners [23,59].

\section{Comparison with other monitoring data}

Our findings regarding the predominance of CB-153 confirm the results of numerous other studies (e.g., [5,60-69]). CB-153 is therefore often used as a marker for PCBs. Regarding Baltic Sea locations, CB-153 concentrations of 2,500 and 2,300 ng/g lw are reported for guillemot eggs (Uria aalge) from the Swedish island Stora Karlsö sampled in 2005 and 2006, respectively [63,65]. These data correspond well to the levels we detected in herring gull eggs from Heuwiese, i.e., 2,650 and 2,670 ng CB-153/g lw in 2005 and 2006.

For the North Sea, no comparative CB-153 data are available, but several studies report on CB-153 in eggs from different North Atlantic locations. At the Faroe Island and Iceland, CB-153 concentrations in Northern fulmar (Fulmaris glacialis) eggs ranged between 1,200 and 7,500 ng/g lw in 2001 and 2002 [61,69]. Comparable concentrations were detected in herring gull eggs from three locations in northern Norway in 2003, i.e., 2,700 to $3,300 \mathrm{ng}$ CB-153/g lw [64], as well as in eggs of the European shag (Phalacrocorax aristotelis) from the Norwegian island Sklinna in 2003 and 2004 (1,640 to 1,810 $\mathrm{ng} / \mathrm{g} \mathrm{lw}$ ) [67], and in eggs of the great black-backed gull (Larus marinus, 420 to 3,400 ng/g lw) and lesser blackbacked gull (Larus fucus, 770 to $3,000 \mathrm{ng} / \mathrm{g} \mathrm{lw}$ ) from Iceland in 2003 [69]. All these data are in good accordance with our findings: In the same time span (2001 to 2004), CB-153 ranged between 1,290 and 3,550 ng/g lw in herring gull eggs from Mellum and between 2,300 and 4,300 $\mathrm{ng} / \mathrm{g}$ lw in eggs from Trischen. Much lower CB-153 levels, i.e., 250 to $400 \mathrm{ng} / \mathrm{g} \mathrm{lw}$, were reported for guillemot eggs from different sites in Iceland, Faroe Islands, and Norway between 2002 and 2005 [64,65,69] and from eggs of the common eider (Somateria mollissima) from Iceland and three Norwegian sites (37 to $450 \mathrm{ng} / \mathrm{g} \mathrm{lw}$ ) in 2003 and $2004[67,69]$. These lower values reflect not only different environmental contamination, but also species-specific differences in feeding habits and metabolisms as reported by Jörundsdóttir et al. [69] for seven seabird species from Iceland where metabolite patterns and CB-153 concentrations varied strongly between species (i.e., 150 to 18,000 ng CB-153/g lw).

Regarding total PCB concentrations, Bustnes et al. [70] report mean levels (sum of 26 congeners) of 1,240 ng/g ww $(\approx 12,580 \mathrm{ng} / \mathrm{g}$ lw calculated with reported lipid concentrations of $9.85 \%$ ) in eggs of the lesser black-backed gull (Larus fuscus intermediatus) collected at the southern Norwegian coast (North Sea) in 2002. In lesser black-backed gulls from Iceland, total PCBs (sum of 12 congeners) amounted to $6,000 \mathrm{ng} / \mathrm{g} \mathrm{lw}$ in 2003 [69]. High median concentrations are reported for eggs of ivory gulls (Pagophila eburnea) from the Russian and Norwegian Arctic regions (sum of 28 congeners 16,000 to $45,500 \mathrm{ng} / \mathrm{g} \mathrm{lw}$ ) in 2006 [71] and for eggs of the peregrine falcon (Falco peregrinus tundris) from South Greenland (sum of 22 congeners $55 \mu \mathrm{g} / \mathrm{g}$ lw $=55,000$ ng/g), sampled between 1986 and 2003 [72]. Both species are top predators and thus strongly exposed to biomagnifying substances like PCBs. Shag eggs from three differently exposed islands of central Norway had total PCB levels (sum of 12 congeners) of 4,590 to $4,690 \mathrm{ng} / \mathrm{g}$ lw in 2003 and 2004, whereas significantly lower levels of 109 to $880 \mathrm{ng} / \mathrm{g}$ lw were detected in eggs of the common eider from the same sites [67]. These findings were ascribed to differences in feeding habits and ecology. In eggs of the Eurasian oystercatcher (Haematopus ostralegus) and common tern (Sterna hirundo) from Trischen, total PCB concentrations (sum of 32 congeners) declined between 1987 and 2008 from $\approx 5,500$ to $<1,000$ $\mathrm{ng} / \mathrm{g}$ ww (common tern) and from $\approx 2,500$ to $<500 \mathrm{ng} / \mathrm{g}$ ww (oystercatcher) [73] (values derived from figures). Specifically, the data for oystercatcher eggs are in good agreement with our findings from Trischen. For the Baltic Sea, similar concentrations were reported in eggs of the little tern (Sterna albifrons) from the east coast of Schleswig-Holstein: Between 1978 and 1996, total PCBs (62 congeners) decreased from $\approx 3,000$ to $600 \mathrm{ng} / \mathrm{g} \mathrm{ww}$ [74]. Our time series at Heuwiese started later. Nevertheless, in 1996, we observed comparable $\Sigma$ PCB levels in herring gull eggs, i.e., $820 \mathrm{ng} / \mathrm{g}$ ww. In 2008, levels had decreased to $460 \mathrm{ng} / \mathrm{g}$ ww which is in good agreement with the data reported for herring gull eggs from the Swedish west coast in the same year (sum of 13 congeners 107 to $355 \mathrm{ng} / \mathrm{g}$ ww; [75]).

\section{Toxicological implications}

OSPAR [76] recommends an ecological quality objective [EcoQO] for total PCBs in eggs of North Sea seabirds of $20 \mathrm{ng} / \mathrm{g}$ ww. The objective was derived for common tern and Eurasian oystercatcher. It may, however, give an indication of safe levels also in herring gull eggs as PCB accumulation is quite similar [77]. All of our egg samples from both the Baltic Sea and North Sea exceed the EcoQO of $20 \mathrm{ng} / \mathrm{g}$ ww by far. Even single congeners, i.e., CB-118 (with one exception at Mellum in 2008), CB-138, -153 and -180 exceed the EcoQO at all three sites during the whole study period. Whether these high levels of PCBs have any effects on herring gull embryos and hence on the herring gull population is not clear. Studies on effects of PCBs on herring gull embryos are not available. In laboratory studies with American kestrels (Falco sparverius), developmental abnormalities and effects on growth were observed at considerably higher PCB egg concentrations $(34 \mu \mathrm{g} / \mathrm{g} \mathrm{ww}$, sum of congeners present in Aroclor 1,$248 ; 1,254 ; 1,260$ ) [78]. However, besides possible differences in species sensitivities, it is always 
problematic to compare laboratory studies with field data. In nature, birds are exposed to a multitude of contaminants and other environmental stressors, and synergistic and additive effects may occur. This makes it extremely difficult to assign effects to one pollutant or stressor only. The only exception may be studies in the vicinity of point sources. For example, Ormerod et al. [79] studied dippers (Cinclus cinclus) at several unpolluted and one PCB-polluted river section in Wales. They found no differences in populations even though PCB levels (sum of $>29$ congeners) in eggs at the polluted site were considerably higher (i.e., $8.35 \mu \mathrm{g} / \mathrm{g}$ lw (and thus comparable to our data) vs. $2.1 \mu \mathrm{g} / \mathrm{g}$ lw at the unpolluted sites). These findings are in line with other studies that report high pollutant levels in bird eggs but with no associated population level effects (e.g., $[15,80])$. Also, for herring gulls at the three ESB sites, no population effects are reported.

\section{PFC}

PFOS was the dominant fluorinated compound in herring gull eggs from all three ESB-sampling sites. PFOA, PFNA, PFDA, PFUnA, PFHxS, and PFHpS were detectable at significantly lower levels, while PFBA, PFHxA, PFBS, and PFDS concentrations were below the respective LOQs in most samples.

During the whole study period, mean PFOS levels in herring gull eggs from the North Sea locations Trischen and Mellum were $91 \pm 32 \mathrm{ng} / \mathrm{g}$ ww (range 46 to $170 \mathrm{ng} / \mathrm{g}$ ) and $67 \pm 19 \mathrm{ng} / \mathrm{g}$ ww (range 39 to $99 \mathrm{ng} / \mathrm{g}$ ), respectively (Figure 4) [see Table S5 in Additional file 1]. For eggs from Trischen, high concentrations were found throughout the period from 1994 to 2000 as well as in the years 1988, 2002, and 2008 and no temporal trends were detectable [see Table S7 in Additional file 1]. In contrast, a significant decreasing trend of $3 \%$ annually was observed for PFOS in eggs from Mellum during the entire study period $(p<0.015)$ and an even stronger trend of $15 \%$ annual decrease between the years 2000 and $2006(p<0.001)$ [see Table S7 in Additional file 1]. In 2007 and 2008, levels increased again.

Baltic Sea eggs contained $67 \pm 41$ ng PFOS/g ww (range 20 to $160 \mathrm{ng} / \mathrm{g}$ ) (Figure 4) [see Table S5 in Additional file $1]$. Despite some inter-year variations, a significant increase $(p<0.046)$ was detectable at this sampling site after 2003 [see Table S7 in Additional file 1].

Concentrations of perfluorinated carboxylic acids [PFCAs] were clearly lower than PFOS levels and differed in composition between North Sea and Baltic Sea eggs.

At both North Sea locations, PFOA was the dominating PFCA with mean egg concentrations of $17 \pm 20 \mathrm{ng} / \mathrm{g} \mathrm{ww}$ (range 2 to $74 \mathrm{ng} / \mathrm{g}$ ) at Trischen and $18 \pm 25 \mathrm{ng} / \mathrm{g} \mathrm{ww}$ (range 3 to $118 \mathrm{ng} / \mathrm{g}$ ) at Mellum [see Table S5 in Additional file 1]. Concentrations decreased during the study period, but since the inter-year variations were quite high, a significant trend was detectable only for eggs from Mellum $(p<0.072)$ [see Table S7 in Additional file 1]. In contrast, the summed-up concentrations of longer-chain PFCAs, namely, PFNA, PFDA, PFUnA, and PFDoA, increased significantly during the entire monitoring period ( $p<0.001$ (Trischen), $p<0.002$ (Mellum)) [see Table S7 in Additional file 1].

At the Baltic Sea location, PFCA egg concentrations were generally lower. Since 1996, PFUnA and PFDA dominated with mean concentrations of $4 \pm 4 \mathrm{ng} / \mathrm{g} \mathrm{ww}$ and $3 \pm 2 \mathrm{ng} / \mathrm{g} w \mathrm{w}$, respectively [see Table S5 in Additional file 1] (Figure 5). With the exception of 2003, concentrations of PFOA were lower (mean $1 \pm 1 \mathrm{ng} / \mathrm{g}$ ww; range < LOQ to $3 \mathrm{ng} / \mathrm{g}$ ). Similar to both North Sea locations, the sums of the concentrations of longer-chain PFCAs, i.e., PFNA, PFDA, PFUnA, and PFDoA, increased significantly $(p<0.001)$ during the study period [see Table S7 in Additional file 1]. This increase may be related to enhanced production volumes of fluorotelomer-based products (e.g., an approximately two-fold increase between 2000 and 2004), which are precursors of PFCAs [9,81,82].

The observed differences in PFCA composition between our North Sea sites on one hand (PFOA dominance) and the Baltic Sea site on the other (more longer-chain PFCAs) might be related to the feeding habits of the respective gull populations, e.g., more demersal feeding in the Baltic Sea and thus an increased uptake of particleassociated longer-chain PFCAs as discussed by Carlsson et al. for eiders [75].

\section{Comparison with other monitoring dato}

The predominance of PFOS among PFCs in seabird eggs is in accordance with other studies (e.g., [36,37,40,67,75, 83-87]) although concentration levels differ considerably between species and sites.

In guillemot eggs from the Swedish island Stora Karlsö, PFOS increased significantly from $25 \mathrm{ng} / \mathrm{g}$ ww in 1968 to $614 \mathrm{ng} / \mathrm{g}$ in 2003. The highest PFOS concentrations were found in $1997(1,324 \mathrm{ng} / \mathrm{g})$ and 1999 (1,023 ng/g) [40]. Bignert et al. [88] report mean PFOS concentrations of $1,475 \mathrm{ng} / \mathrm{g}$ ww in guillemot eggs from Stora Karlsö in 2007 and a significant increasing trend of $7 \%$ to $10 \%$ per year between the late 1960 s and the early 2000s. During the last 10 years, however, no further increase was detectable. Löfstrand et al. [84] compared different northern European locations (i.e., Baltic Sea (Stora Karlsö), Norway, Faroer Islands, and Iceland) and found the highest PFOS levels in guillemot eggs from the Baltic Sea with a mean concentration of $400 \mathrm{ng} / \mathrm{g}$ ww in 2003. Compared to Stora Karlsö, eggs from our Baltic Sea sampling site had considerably lower PFOS levels (20 to $159 \mathrm{ng} / \mathrm{g} \mathrm{ww}$ ).

No comparative data are available for PFOS in bird eggs from North Sea locations. In herring gull eggs from 


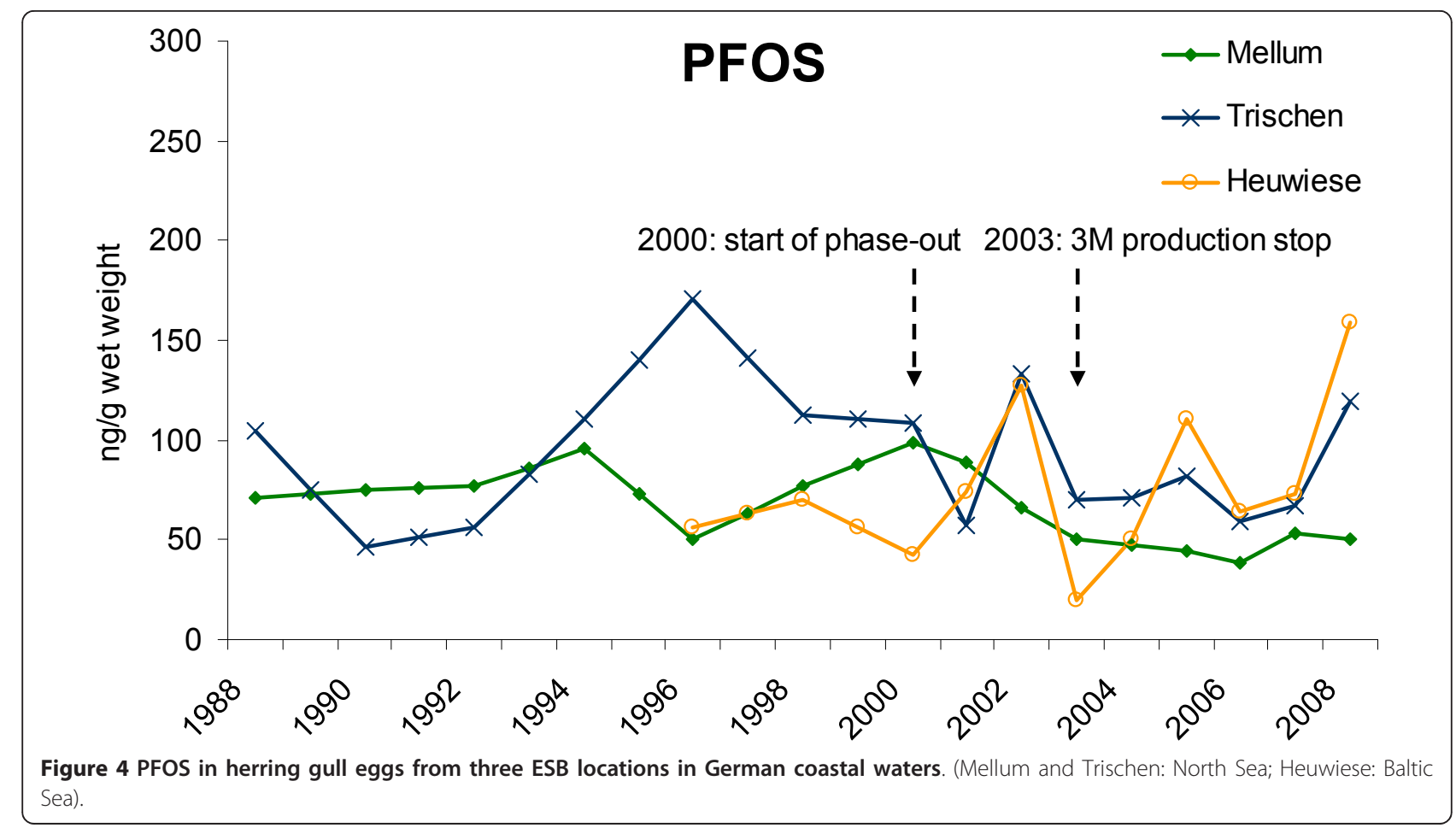

northern Norway, Verreault et al. [83] detected mean PFOS levels of 21 to $42 \mathrm{ng} / \mathrm{g}$ ww in 1983, 1993, and 2003 with a two-fold increase between 1983 and 1993 and a leveling-off thereafter. Eggs of eiders and shags from different locations in Norway had mean PFOS levels of 15 to $37 \mathrm{ng} / \mathrm{g} w \mathrm{ww}$ (eider) and $37 \mathrm{ng} / \mathrm{g}$ ww (shag) in 2003 and 2004 [67]. Slightly higher PFOS levels are reported for eggs of ivory gulls from the

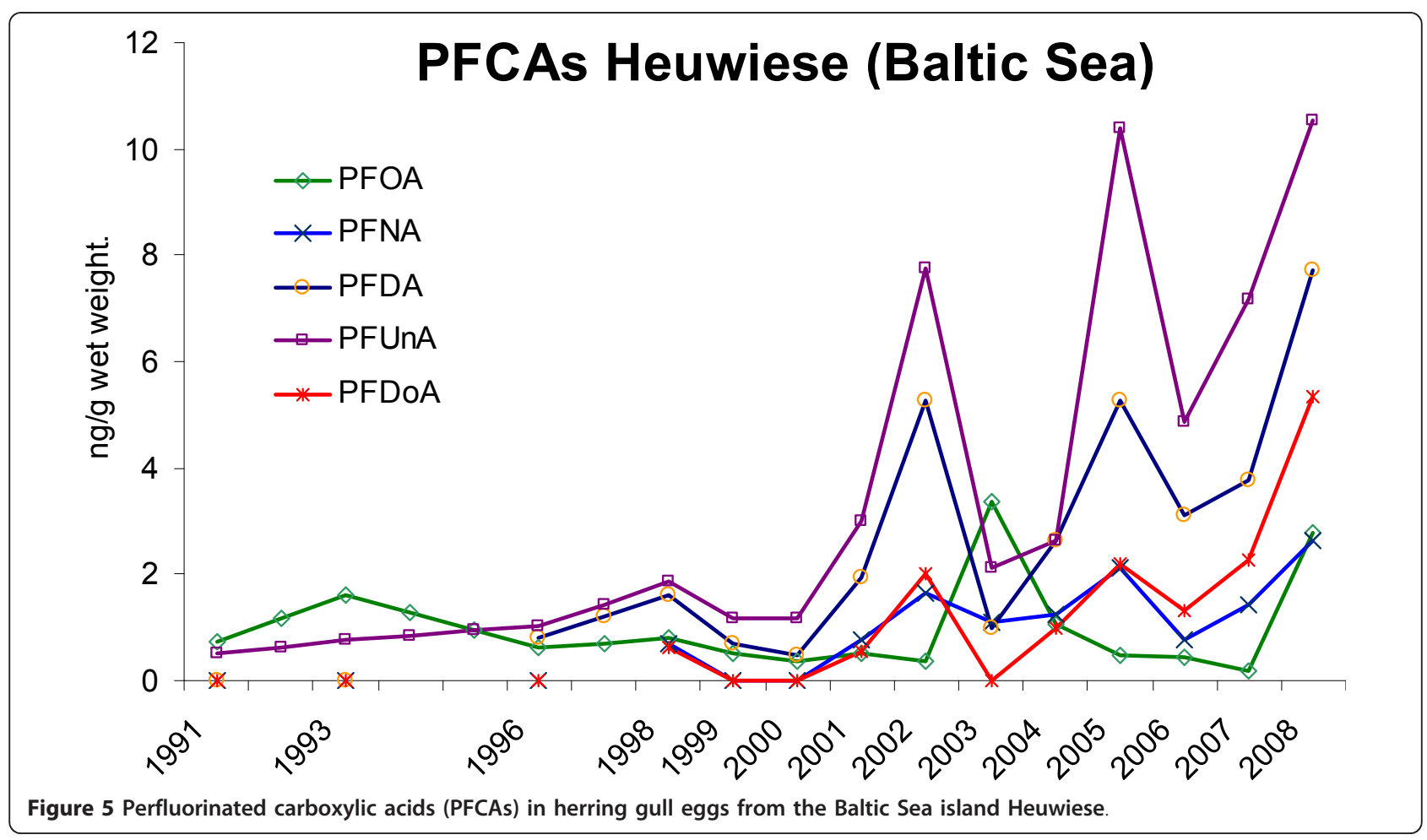


Russian and Norwegian Arctic, i.e., 58 to $79 \mathrm{ng} / \mathrm{g}$ ww in 2006 [71]. Compared to our data, herring gulls, eiders, and shags from Norway were slightly less contaminated, whereas ivory gulls of the Arctic were within the same range.

In studies dealing with PFCAs in seabird eggs, typically longer-chain PFCAs (> $8 \mathrm{C}$-atoms) predominate, while PFOA is often not detected at all [12,36,71,83-87]. This has been ascribed to a positive correlation between carbon chain length and bioaccumulation for PFC with 8 to 12 carbons [34].

Löfstrand et al. [84] report mean PFNA, PFUnA, and PFDoA levels of $48 \mathrm{ng} / \mathrm{g}, 82 \mathrm{ng} / \mathrm{g}$, and $18 \mathrm{ng} / \mathrm{g} \mathrm{ww}$, respectively, in guillemot eggs from the Baltic Sea island Stora Karlsö in 2003. PFOA and PFDA were not detected at all. Compared to herring gull eggs from our Baltic Sea location, guillemots from Stora Karlsö had clearly higher PFNA, PFUnA, and PFDoA concentrations (Heuwiese (2003): PFNA $1.1 \mathrm{ng} / \mathrm{g}$, PFUnA 2.1 ng/g, PFDoA < $0.5 \mathrm{ng} / \mathrm{g}(\mathrm{LOQ}))$, whereas we detected higher levels of PFOA (3.3 ng/g) and PFDA (1.0 ng/g).

No comparative PFCA-data are available for bird eggs from the North Sea. However, for guillemot eggs from Iceland, the Faroer Islands, and Norway [84]; herring gull eggs from northern Norway [83]; and ivory gull eggs from the Russian and Norwegian Arctic [71], a predominance of longer-chain PFCA with $>8 \mathrm{C}$-atoms was reported although concentration levels varied strongly.

It needs to be clarified whether differences in feeding habits of the gulls, in contamination of sites, or in sample treatment are responsible for our contradictory findings in North Sea samples (i.e., PFOA dominance). With respect to sample treatment, one possible explanation could be that different extraction procedures were applied. Our protocol includes both alkaline and acidic treatments and is assumed to characterize the bioavailable fraction of PFCs. Since acidic conditions are applied, the procedure simulates processes during food digestion. This may result in higher extraction efficiencies for PFOA as compared to other methods.

\section{Toxicological implications}

Based on dietary exposure studies with mallard ducks (Anas platyrhynchos) and the northern bobwhite quail (Colinus virginatus), Newsted et al. [89] calculated toxicity reference values [TRV] and predicted no-effect concentrations [PNEC] for PFOS based on characteristics of avian top predators. The conservative egg yolk-based TRV and PNEC were $1.7 \mu \mathrm{g}$ PFOS/mL and $1 \mu \mathrm{g}$ PFOS/ $\mathrm{mL}$, respectively (assumption $1 \mathrm{~mL}$ egg yolk $\approx 1 \mathrm{~g}$ ). Compared to these values, the PFOS concentrations found in our study are much lower and - assuming a similar sensitivity of both species - should alone not pose a threat to herring gull embryos. For PFCAs, corresponding reference values are not yet available. Again, it must be kept in mind that PFOS is not the only contaminant detected in gull eggs and that additive/synergistic effects with other pollutants are likely to occur. Compared to organochlorines (e.g., PCBs and DDT) PFCs seem to be less critical for gull populations as Bustness et al. [90] have demonstrated for lesser black-backed gulls (Larus fuscus fuscus) from Norway.

\section{PBDE}

During the study period, similar PBDE concentrations (sum of 35 congeners) were observed in herring gull eggs from the North Sea island Mellum and the Baltic Sea location Heuwiese (Mellum: 282 to 2,059 ng/g lw, mean $798 \pm 418 \mathrm{ng} / \mathrm{g}$; Heuwiese: 232 to $2,021 \mathrm{ng} / \mathrm{g} \mathrm{lw}$, mean $846 \pm 471 \mathrm{ng} / \mathrm{g})$. PBDE concentrations in eggs from the North Sea island Trischen were generally lower (116 to $1,722 \mathrm{ng} / \mathrm{g} \mathrm{lw}$, mean $546 \pm 428 \mathrm{ng} / \mathrm{g}$ ) [see Table S6 in Additional file 1]. The only exception was in 1992 with unusual high concentrations at Trischen.

The congener distribution was more or less the same at all three locations with a clear predominance of BDE47 and BDE-99 until 2005/2006 [see Table S6 in Additional file 1]. Roughly, congener patterns can be described as follows:

- North Sea/Mellum: BDE-99 > BDE-47 > BDE209/-100/-153 > BDE-183 > BDE-154 > BDE-85;

- North Sea/Trischen: BDE-47/-99 > BDE-100/-209

$>$ BDE-153 > BDE-183 > BDE-154 > BDE-85;

- Baltic Sea/Heuwiese: BDE-47/-99 > BDE-100 > BDE-153/-183/-209/-154 > BDE-85.

All other congeners were detected at considerably lower concentrations if at all. During the monitoring period, BDE-47 and -99 decreased markedly. Declining levels were also observed for most other congeners except BDE-209.

The major congeners can be allocated to three technical PBDE formulations of commercial and environmental relevance, i.e., Penta-BDE, Octa-BDE, and Deca-BDE. Congeners BDE-47, $-99,-100$, and -153 are the major components of Penta-BDE, whereas Octa-BDE contains mainly BDE-183 and varying amounts of up to 10 other congeners including BDE-196, -197, -203, -207, and -209 [91]. Technical Deca-BDE consists of > 97\% BDE-209 $[91,92]$. In data evaluation, this was taken into account by combing the relevant congeners of Penta-, Octa-, and Deca-BDE, respectively, thus linking concentration trends in herring gull eggs to commercial products (Figures 6 and 7).

The results clearly show that Penta-BDE was the major contaminant of herring gull eggs at all three locations even though Deca-BDE production volumes were considerably higher $[43,91]$. Penta-BDE concentrations 


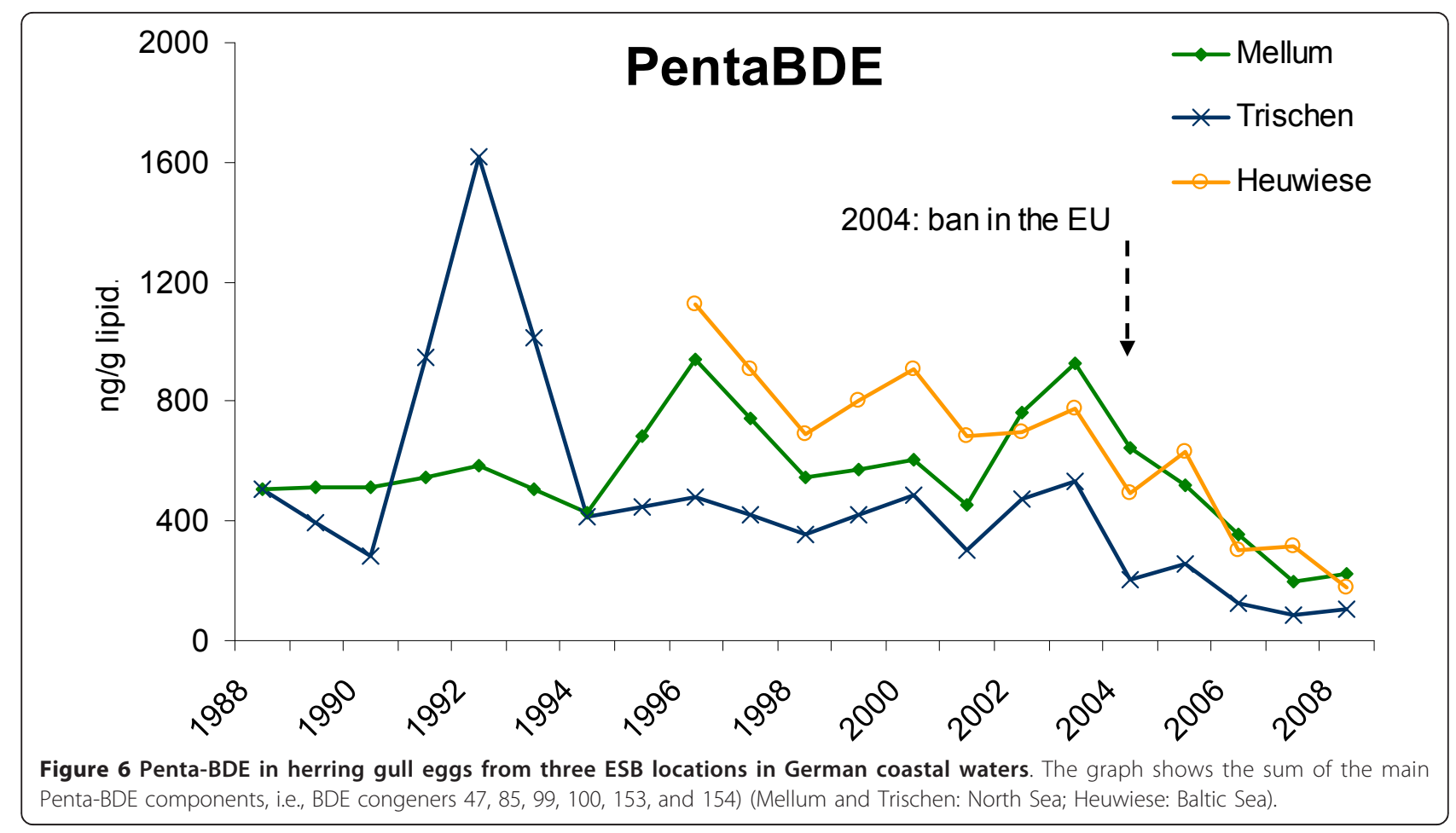

(sum of BDE-47, -85, -99, -100, -153, and -154) ranged between 89 and 1,615 ng/g lw at both North Sea locations with generally higher levels in eggs from Mellum (Figure 6). In 1992, however, an exceptionally high Penta-BDE level was detected in eggs from Trischen which involved all five congeners. It is therefore hypothesized that a single event, e.g., an accident or spill may be the cause. Penta-BDE levels at the Baltic Sea location Heuwiese ranged between 176 and 1,128 ng/g lw and were thus comparable or even slightly higher than

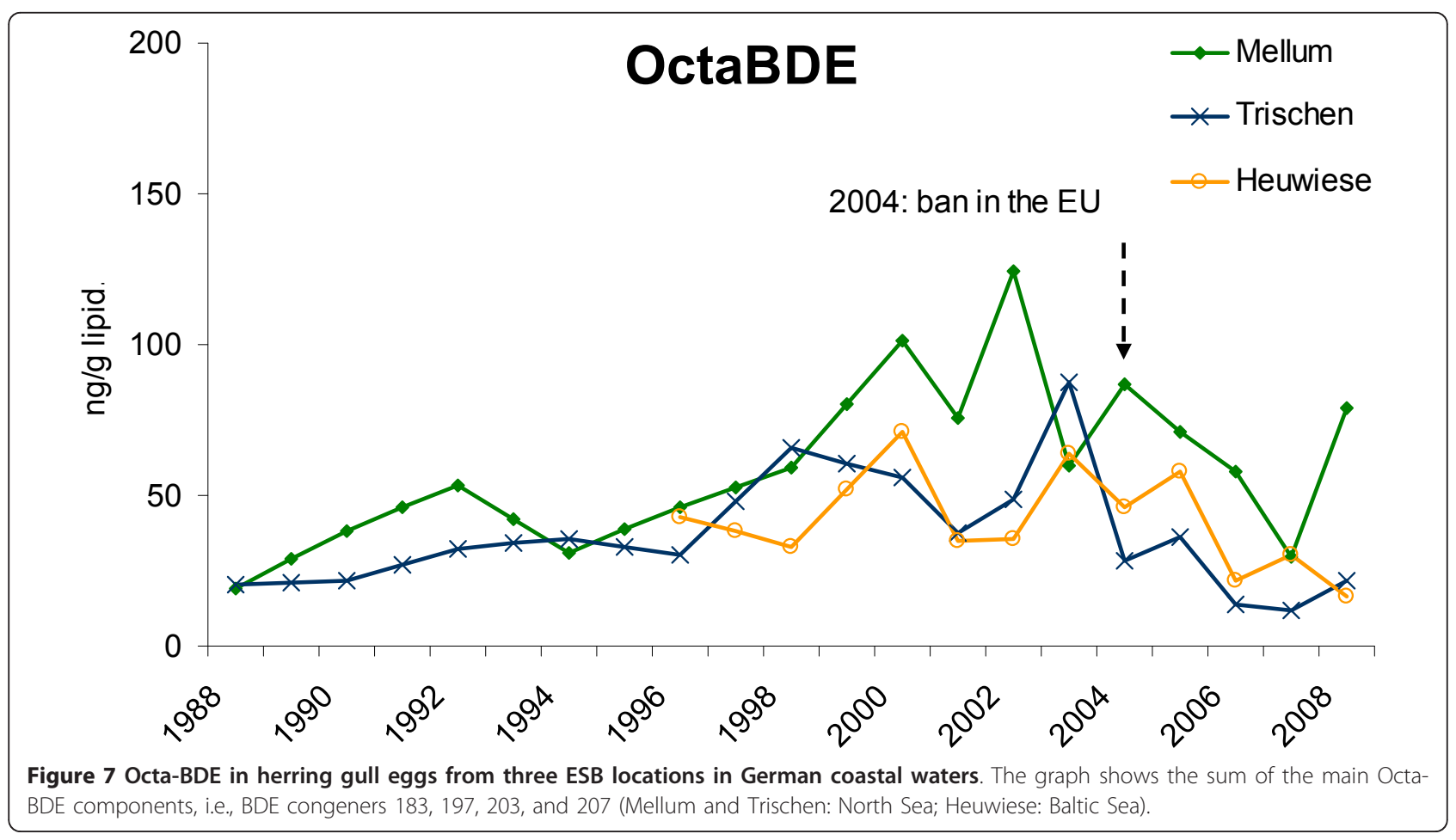


levels at Mellum. At all three locations, Penta-BDE decreased significantly during the study period $(p<0.002$ (Mellum), $p<0.005$ (Trischen), and $p<0.001$ (Heuwiese)) [see Table S7 in Additional file 1]. The declines started already before the EU-wide ban in 2004 but are, nevertheless, likely to be related to the political discussion (e.g., reduction and substitution already before the final ban). Fast declines in environmental PBDE concentrations as a consequence of decreased emissions have also been described by others (e.g., $[63,93,94]$ ).

Levels of Octa-BDE (sum of BDE-183, 197, 203, and 207) were considerably lower than those of Penta-BDE. At both North Sea locations, egg concentrations varied between 12 and $124 \mathrm{ng} / \mathrm{g} \mathrm{lw}$, again with mostly higher concentrations at Mellum (Figure 7). Similar levels were detected in eggs from the Baltic Sea island Heuwiese (i.e., 17 and $101 \mathrm{ng} / \mathrm{g} \mathrm{lw}$ ). At all three locations, OctaBDE increased until 2002 and 2003, respectively (significant only at Mellum (1988 to 2002), p < 0.001; and Trischen (1988 to 2003), p < 0.002) [see Table S7 in Additional file 1]. Thereafter, concentrations decreased at all sites (significant only at Heuwiese $(p<0.022,2003$ to 2008) [see Table S7 in Additional file 1]. In 2008, however, Octa-BDE had increased again in eggs from both North Sea locations. Next years' data will show whether this is indicative of a new rise.

Except for the year 2000, concentrations of Deca-BDE (BDE-209) ranged between 3 and $198 \mathrm{ng} / \mathrm{g}$ lw in North Sea eggs with temporarily high inter-year variations. Eggs from Heuwiese had Deca-BDE levels of 22 to $103 \mathrm{ng} / \mathrm{g}$ lw. In 2000, however, unusually high concentrations of 1,328 ng/g lw (Mellum), $680 \mathrm{ng} / \mathrm{g}$ (Trischen), and $995 \mathrm{ng} / \mathrm{g}$ (Heuwiese) were analyzed. The values in year 2000 should be handled with caution as the surprising high levels have not been confirmed yet. In contrast to Penta-BDE and Octa-BDE, Deca-BDE increased with time at all three ESB locations; a significant trend, however, was detected only at Mellum $(p<0.027)$ [see Table S7 in Additional file 1]. Deca-BDE was restricted in the EU only in 2008, so the following years will show whether these measures are as effective as the bans of Penta- and Octa-BDE.

\section{Comparison with other monitoring data}

In accordance with our findings, congeners BDE-47, -99, and -100 have been described as dominant congeners in marine bird eggs in numerous studies (e.g., [10,43,65,75, 71,94-97]. They are more efficiently bioaccumulated than higher brominated PBDEs [43].

Comparative data for PBDE in marine bird eggs from the Baltic Sea are available for guillemot eggs from the island Stora Karlsö [65,93] and eider and herring gull eggs from the Swedish west coast [75]. Between 1969 and 2003, BDE-47 in guillemot eggs from Stora Karlsö ranged between 45 and 1,100 ng/g lw, while levels of BDE-99 and -100 were lower (i.e., 2.0 to $190 \mathrm{ng} / \mathrm{g}$ and 1.0 to 100 ng/g, respectively, with BDE-100 analyzed only until 1997 [65,93]). Concentrations increased until the end of the 1980s, followed by a rapid decrease [93]. These values are comparable to the concentrations we detected in herring gull eggs from our Baltic Sea location. Considerably lower concentrations were detected in eggs of eiders and herring gulls from the Swedish west coast in 2008 [75]. In both species, BDE- 47 was the most abundant congener with mean concentrations of $0.3 \mathrm{ng} / \mathrm{g}$ ww $(\approx 1.6 \mathrm{ng} / \mathrm{g}$ lw, calculated with a mean lipid content of $18 \%)$ in eider eggs and $2.6 \mathrm{ng} / \mathrm{g}$ ww $(\approx 43 \mathrm{ng} / \mathrm{g} \mathrm{lw}$, mean lipid content $6 \%$ ) in herring gull eggs. In the same year, $101 \mathrm{ng}$ BDE$47 / \mathrm{g}$ lw was detected in our Baltic Sea samples.

Again, no comparative data are available for the North Sea, but several studies have analyzed PBDEs at different locations in the North Atlantic. For herring gull eggs from North Norway, Helgason and et al. [94] report rather high BDE-47 concentrations of 350 to $497 \mathrm{ng} / \mathrm{g}$ lw in 1983, 1993, and 2003 and considerably lower levels of other congeners. Between 1983 and 1993, levels increased while they decreased or stabilized thereafter. Lower BDE47 levels were detected in eggs of ivory gulls from four locations in the Russian and Norwegian Arctic (i.e., 25 and 208 ng/g lw in 2006/2007 [71]. Total PBDE concentrations (median of the sum of congeners -28, -47 , $-99,-100,-153,-154,-209)$ at these sites amounted to 51 to $302 \mathrm{ng} / \mathrm{g}$ lw. For guillemot from different North Atlantic locations (Iceland, Faroe Islands, and three Norwegian sites) [65] and fulmars from Faroe Islands [61], mean egg concentrations of 5.9 to $38 \mathrm{ng}$ BDE-47/g lw are reported for years 2000 to 2003 with highest levels in Iceland. Similar BDE-47 concentrations are reported for eggs of the common eider from three differently exposed locations in Norway (2 to $20 \mathrm{ng} / \mathrm{g} \mathrm{lw}$ ) and eggs of European shags from one of these sites ( 24 and $27 \mathrm{ng} / \mathrm{g} \mathrm{lw}$ ) in 2003 and 2004 [67]. For comparison, between years 2000 and 2007, BDE-47 levels in herring gull eggs from our North Sea locations ranged between 43 and $275 \mathrm{ng} / \mathrm{g} \mathrm{lw}$.

As already discussed for PCBs and PFCs, the observed differences between locations and species are probably related to differences in local contamination as well as to different feeding habits, metabolism, and ecology. PBDEs are emitted not only by industrial plants, but also by households, e.g., from electronic equipment, cars, furniture, carpets, etc., which means that the surroundings of areas with high population densities are likely to be more contaminated compared to more remote sites $[65,67,94]$. On the other hand, species-specific properties like feeding habits and metabolism also influence the contaminant levels in bird eggs $[64,67,75]$ and thus contribute to the reported differences.

\section{Toxicological implications}

No reference values for PBDEs are available. Fernie et al. $[46,98]$ report effects on reproduction and behavior of 
the American kestrel (Falco spaverius) after dietary exposure to two environmental concentrations of the commercial Penta-BDE formulation DE-71 which resulted in egg concentrations of $288 \pm 33 \mathrm{ng} / \mathrm{g}$ and $1131 \pm 95 \mathrm{ng} / \mathrm{g}$ ww (sum of PBDEs), respectively. Following air cell injection, embryonic survival of American kestrels was affected at absorbed Penta-BDE concentrations of $32 \mu \mathrm{g} / \mathrm{g}$ egg lw [99]. In herring gull eggs from all three ESB sites, the sum of all 35 investigated PBDE congeners ranged between 116 and 2,059 ng/g lw (corresponding to 11 to $119 \mathrm{ng} / \mathrm{g} \mathrm{ww}$ ) during the whole monitoring period and was thus lower than the effect concentrations for Penta-BDE in American kestrels. Provided that the sensitivity of American kestrels and herring gulls is comparable, PBDE alone would not lead to effects on reproduction and embryonic survival. As already stated for PCBs and PFCs, however, herring gulls are exposed to a broad cocktail of contaminants, and additive/synergistic effects must be taken into account, e.g., as observed for PCBs and PBDEs [100].

\section{Conclusions}

Effects of regulatory measures were clearly observable for PCBs and PBDEs. PCBs in herring gull eggs have decreased during the study period at all three sites following the EU-wide ban in 1985. Nevertheless, PCB levels are still high and exceed the common tern/oystercatcher EcoQOs of $20 \mathrm{ng} / \mathrm{g}$ ww by far. However, these high concentrations are obviously not critical for the herring gulls because population level effects are not observed at any of the three ESB sites.

In the context of the EU-wide ban of Penta- and OctaBDE products in 2004 [20], concentrations of the respective congeners, mainly BDE-47, $-99,-100$ and -183 , declined in herring gull eggs. In contrast, no decreases were observed for BDE-209, the major component of commercial Deca-BDE which even increased at one site. Since July 2008, the use of Deca-BDE is restricted within the EU (curia.europa.eu; case C-14/06), and further monitoring will show whether this is reflected in herring gull eggs.

In contrast to PCBs and PBDEs, the voluntary phase-out in production of PFOS and respective precursor substances declared by the main manufacturer $3 \mathrm{M}$ in 2000 [101] as well as the restricted use of PFOS in the European Union is currently not mirrored in decreasing PFOS concentrations in herring gull eggs from two out of three ESB locations. Decreases in PFOS after 2000 were detectable only in eggs from the North Sea island Mellum. At both other sites, PFOS concentrations varied between years and even increased in Heuwiese. Concurrently, an increase of PFCAs with $>8 \mathrm{C}$-atoms is noticeable in herring gull eggs since 2000 which may be related to an increased fluorotelomer production (precursors of PFCAs) compensating the PFOS phase-out. Taking their physicochemical properties into account, it is likely that PFOS responds quite differently to the cessation of production compared to lipophilic compounds like PCBs and PBDEs [40]. The coming years will show the effectiveness of the regulatory measures now under way.

\section{Additional material}

Additional file 1: Supporting information. A file containing supplementary text and tables on PCB, PFC, and PBDE analyses.

\section{Acknowledgements}

The funding of the German Environmental Specimen Bank project partners by the German Federal Ministry of the Environment, Nature Conservation and Nuclear Safety is acknowledged. The authors thank especially the following members of the ESB teams for their valuable contributions: Sonja Uhlig, Martin Weingärtner (both Fraunhofer IME), Roland Klein, Markus Quack, Gerhard Wagner (all University of Trier), and Dirk Pfleger (Eurofins GfA).

\section{Author details}

${ }^{1}$ Fraunhofer Institute for Molecular Biology and Applied Ecology (Fraunhofer IME), Schmallenberg 57377, Germany 2 Eurofins GfA Lab Service GmbH, Hamburg 21079, Germany ${ }^{3}$ Federal Environment Agency, Dessau-Rosslau 06813, Germany

\section{Authors' contributions}

AF assessed the data, drafted the manuscript, did the literature research, and performed the statistical analysis. HR is responsible for the ESB sample preparation and data compilation and contributed to the drafting of the manuscript. HJ carried out the chemical analysis of PFCs. JM was responsible for the PFC data compilation. FN was responsible for the analytical data of PCBs and PBDEs and edited the presentation of the data. CSK coordinated the research and funding, evaluated the data, and contributed to the drafting of the manuscript. All authors read and approved the final manuscript.

\section{Competing interests}

The authors declare that they have no competing interests.

Received: 14 November 2011 Accepted: 6 February 2012 Published: 6 February 2012

\section{References}

1. Muir DC, Wagemann R, Hargrave BT, Thomas DJ, Peakall DB, Norstrom RJ: Arctic marine ecosystem contamination. Sci Tot Environ 1992, 122:75-134.

2. Giesy JP, Kannan K: Global distribution of perfluorooctane sulfonate in wildlife. Environ Sci Technol 2001, 35:1339-1342.

3. Ellis DA, Martin J, De Silva AO, Hurley MD, Mabury SA, Sulbaek Andersen MP, Wallington TJ: Degradation of fluorotelomer alcohols: a likely atmospheric source of PFCA. Environ Sci Technol 2004, 3:3316-3321.

4. Martin JW, Smithwick MM, Braune BM, Hoekstra PF, Muir DCG, Mabury SA: Identification of long-chain perfluorinated acids in biota from the Canadian Arctic. Environ Sci Technol 2004, 38:373-380.

5. Vander Pol SS, Becker PR, Kucklick JR, Pugh RS, Roseneau DG, Simiac KS: Persistent organic pollutants in Alaskan murre (Uria spp.) eggs: geographical, species, and temporal comparisons. Environ Sci Technol 2004, 38:1305-1312.

6. Vorkamp K, Christensen JH, Glasius M, Riget FF: Persistent halogenated compounds in black guillemots (Cepphus grille) from Greenland - levels, compounds patterns and spatial trends. Mar Pollut Bull 2004, 48:111-121.

7. Braune BM, Outridge PM, Fisk AT, Muir DC, Helm PA, Hobbs K, Hoekstra PF, Kuzyk ZA, Kwan M, Letcher RJ, Lockhart WL, Norstrom RJ, Stern GA, Stirling I: Persistent organic pollutants and mercury in marine biota of 
the Canadian Arctic: an overview of spatial and temporal trends. Sci Tot Environ 2005, 351-352:4-56.

8. Braune BM, Mallory ML, Gilchrist HG, Letcher RJ, Drouillard KG: Levels and trends of organochlorines and brominated flame retardants in ivory gull eggs from the Canadian Artic, 1976 to 2004. Sci Tot Environ 2007, 378:403-417.

9. Butt CM, Mabury SA, Muir DCG, Braune BM: Prevalence of long-chained perfluorinated carboxylates in seabirds from the Canadian Arctic between 1975 and 2004. Environ Sci Techno 2007, 41:3521-3528.

10. Corsolini S, Berghesi N, Schiamone A, Focardi S: Polybrominated dipheny ethers, polychlorinated dibenzo-dioxins, -furans, and biphenyls in three species of Antarctic penguins. Env Sci Pollut Res 2007, 14:421-429.

11. Kelly BC, Ikonomou MI, Blair JD, Surridge B, Hoover D, Grace R, Gobas FAPC: Perfluoroalkyl contaminants in an arctic marine food web: trophic magnification and wildlife exposure. Environ Sci Technol 2009, 43:4037-4043.

12. Schiavone A, Corsolini S, Kannan K, Tao L, Trivelpiece W, Torres D Jr, Focardi S: Perfluorinated contaminants in fur seal pups and penguin eggs from South Shetland, Antarctica. Sci Tot Environ 2009, 407:3899-3904.

13. Tomy GT, Pleskach K, Ferguson SH, Hare J, Stern G, Maclnnis G, Marvin CH, Loseto L: Trophodynamics of some PFCs and BFRs in a western Canadian Arctic marine food web. Environ Sci Technol 2009, 43:4076-4081.

14. Yogui GT, Sericano JL: Levels and pattern of polybrominated diphenyl ethers in eggs of Antarctic seabirds: endemic versus migratory species. Environ Pollut 2009, 157:975-980.

15. Letcher RJ, Bustnes JO, Dietz R, Jenssen BM, Jørgensen EH, Sonne C, Verreault J, Vijayan MM, Gabrielsen GW: Exposure and effects assessment of persistent organohalogen contaminants in arctic wildlife and fish. Sci Tot Environ 2010, 408:2995-3043.

16. Butt CM, Berger U, Bossi R, Tomy GT: Levels and trends of poly- and perfluorinated compounds in the arctic environment. Sci Tot Environ 2010, 408:2936-2965.

17. Stockholm Convention on Persistent Organic Pollutants (POPS). [http:// chm.pops.int/Portals//Repository/convention_text/UNEP-POPS-COP_ CONVTEXT-FULL.English.PDF].

18. UNEP Report of the Conference of the Parties of the Stockholm Convention on Persistent Organic Pollutants on the Work of its Fourth Meeting, Geneva, 4-8 May 2009 (DRAFT) UNEP/POPS/COP.4/38. [http:// chm.pops.int/Portals/0/Repository/COP4/UNEP-POPS-COP.4-38.English.pdf].

19. Council Directive 85/467/EEC of 1 October 1985 Amending for the Sixth Time (PCBs/PCTs) Directive 76/769/EEC on the Approximation of the Laws, Regulations and Administrative Provisions of the Member States Relating to Restrictions on the Marketing and Use of Certain Dangerous Substances and Preparations. [http://eur-lex.europa.eu/LexUriServ/ LexUriServ.do?uri=OJ:L:1985:269:0056:0058:EN:PDF].

20. EU Directive 2003/11/EC of the Parliament and of the Council of 6 February 2003 Amending for the 24th time Council Directive 76/769/ EEC Relating to Restrictions on the Marketing and Use of Certain Dangerous Substances and Preparations (pentabromodiphenyl ether, octabromodiphenyl ether). Official Journal of the European Union, European Legislation 42:45-46[http://eur-lex.europa.eu/LexUriServ/LexUriServ. do?uri=OJ:L:2003:042:0045:0046:EN:PDF].

21. International Programme on Chemical Safety: Environmental Health Criteria 140: Polychlorinated Biphenyls and Terphenyls. Geneva , 21993.

22. Verreault J, Villa RA, Gabrielsen GW, Skaare JU, Letcher RJ: Maternal transfer of organohalogen contaminants and metabolites to eggs of Arcticbreeding glaucous gulls. Environ Pollut 2006, 144:1053-1060.

23. Beyer A, Biziuk M: Environmental fate and global distribution of polychlorinated biphenyls. Rev Environ Contam Toxicol 2009, 201:137-158.

24. German Federal Environment Agency: Do without per- and polyfluorinated chemicals and prevent their discharge into the environment.[http://www.umweltdaten.de/publikationen/fpdf-1/3818.pdf].

25. Lau C, Butenhoff JL, Rogers JM: The developmental toxicity of perfluoroalkyl acids and their derivates. Toxicol Appl Pharmacol 2004, 198:231-241.

26. Beach SA, Newsted JL, Coady K, Giesy JP: Ecotoxicological evaluation of perfluorooctane sulfonate (PFOS). Rev Environ Contam Toxicol 2006, 186:133-174

27. Houde M, Martin JW, Letcher RJ, Solomon KR, Muir DCG: Biological monitoring of polyfluoroalkyl substances: a review. Environ Sci Technol 2006, 40:3463-3473.
28. Sinclair E, Mayack DT, Roblee K, Yamashita N, Kannan K: Occurrence of perfluoroalkyl surfactants in water, fish, and birds from New York State. Arch Environ Contam Toxicol 2006, 50:398-410.

29. Haukås M, Berger U, Hop H, Gulliksen B, Gabrielsen GW: Bioaccumulation of per- and polyfluorinated alkyl substances (PFAS) in selected species from the Barents Sea food web. Environ Pollut 2007, 148:360-371.

30. Lau C, Anitole K, Hodes C, Lai D, Pfahles-Hutchens A, Seed J: Perfluoroalkyl acids: a review of monitoring and toxicological findings. Toxicol Sci 2007, 99:366-394.

31. Andersen ME, Butenhoff JL, Chang SC, Farrar DG, Kennedy GL Jr, Lau C, Olsen GW, Seed J, Wallace KB: Review: perfluoroalkyl acids and related chemistries - toxicokinetics and modes of action. Toxicol Sci 2008, 102:3-14.

32. Conder JM, Hoke RA, de Wolf W, Russell MH, Buck RC: Are PFCAs bioaccumulative? A critical review and comparision with regulatory criteria and persistent lipophilic compounds. Environ Sci Technol 2008, 42:995-1003.

33. Van den Heuvel JP, Kuslikis BI, Peterson RE: Covalent binding of perfluorinated fatty acids to proteins in the plasma, liver and testes of rats. Chem Biol Interact 1992, 82:317-328.

34. Martin JW, Mabury SA, Solomon KR, Muir DCG: Bioconcentration and tissue distribution of perfluorinated acids in rainbow trout (Oncorhynchus mykiss). Environ Toxicol Chem 2003, 22:196-204.

35. Jones PD, Hu W, de Coen W, Newsted JL, Giesy JP: Binding of perfluorinated fatty acids to serum proteins. Environ Toxicol Chem 2003, 22:2639-2649.

36. Verreault J, Houde M, Gabrielsen GW, Berger U, Haukås M, Letcher RJ, Muir DCG: Perfluorinated alkyl substances in plasma, liver, brain, and eggs of glaucous gulls (Larus hyperboreus) from the Norwegian Arctic. Environ Sci Technol 2005, 39:7439-7445.

37. Holmström KE, Berger U: Tissue distribution of perfluorinated surfactants in common guillemot (Uria aalge) from the Baltic Sea. Environ Sci Technol 2008, 42:5879-5884.

38. Herzke D, Huber S, Berger U, Nygård T: Perfluorinated organic compounds compared to brominated and chlorinated organic pollutants in European shag (Phalacrocorax aristotelis) and common eider (Somateria mollissima) from Norway. Organohalogen Compounds 2006, 68:667-670.

39. Bustnes OJ, Erikstad KE, Bakken V, Mehlum F, Skaare JU: Feeding ecology and the concentration of organochlorines in glaucous gulls. Ecotoxicol 2000, 9:175-182

40. Holmström KE, Järnberg $U$, Bignert $\mathrm{A}$ : Temporal trends of PFOS and PFOA in guillemot eggs from the Baltic Sea, 1968-2003. Environ Sci Technol 2005, 39:80-84.

41. Bustnes JO, Borgå K, Erikstad KE, Lorentsen SH, Herzke D: Perfluorinated, brominated, and chlorinated contaminants in a population of lesser black-backed gulls (Larus fuscus). Environ Toxicol Chem 2008, 27:1383-1392.

42. WHO: Environmental Health Criteria 162:Brominated Diphenyl Ethers. Geneva 1994.

43. De Wit C: An overview of brominated flame retardants in the environment. Chemosphere 2002, 46:583-624.

44. Agency for Toxic Substances and Disease Registry: ToxFAQs ${ }^{\text {TM }}$ for polybrominated diphenyl ethers (PBDEs).[http://www.atsdr.cdc.gov/ tfacts68-pbde.pdf].

45. Verreault J, Letcher RJ, Ropstad E, Dahl E, Gabrielsen GW: Organohalogen contaminants and reproductive hormones in incubating glaucous gulls (Larus hyperboreus) from the Norwegian Arctic. Environ Toxicol Chem 2006, 25:2990-2996.

46. Fernie KJ, Shutt JL, Letcher RJ, Ritchie IJ, Bird DM: Environmentally relevant concentrations of DE-71 and $\mathrm{HBCD}$ alter eggshell thickness and reproductive success of American kestrels. Environ Sci Technol 2009, 43:2124-2130

47. Zhang K, Wan Y, An L, Hu J: Trophodynamics of polybrominated diphenyl ethers and methoxylated polybrominated diphenyl ethers in a marine food web. Environ Toxicol Chem 2010, 29:2792-2799.

48. Van den Steen E, Jaspers VLB, Covaci A, Neels H, Eens M, Pinxten R. Maternal transfer of organochlorines and brominated flame retardants in blue tits (Cyanistes caeruleus). Environ Int 2009, 35:69-75.

49. Henny CJ, Kaiser JL, Grove RA, Johnson BL, Letcher RJ: Polybrominated diphenyl ether flame retardants in eggs may reduced reproductive success of ospreys in Oregon and Washington, USA. Ecotoxicol 2009, 18:802-813. 
50. In Umweltprobenbank des Bundes - Verfahrensrichtlinien. Edited by: Umweltbundesamt. Berlin: Erich Schmidt Verlag; 1996:

51. Paulus M, Klein R, Wagner G, Müller P: Biomonitoring and environmental specimen banking. Environ Sci Pollut Res 1996, 3:169-177.

52. Emons H, Schladot JD, Schwuger MJ: Environmental specimen banking in Germany - present state and further challenges. Chemosphere 1997, 34:1875-1888.

53. BMU - Federal Ministry for the Environment: Nature Conservation and Nuclear Safety, German Environmental Specimen Bank - Concept Berlin: Federal Environment Agency (Umweltbundesamt); 2000.

54. Rüdel H, Müller J, Jürling H, Bartel-Steinbach M, Koschorreck J: Survey of patterns, levels, and trends of perfluorinated compounds in aquatic organisms and bird eggs from representative German ecosystems. Environ Sci Pollut Res 2011, 18:1457-1470.

55. Koglin D, Backhaus F, Schladot JD: Particle size distribution in ground biological samples. Chemosphere 1997, 34:2041-2047.

56. Paulus M, Bartel M, Klein R, Neitzke M, Nentwich K, Quack M, Wagner G: Guideline for sampling and sample treatment: herring gull (Larus argentatus).[http://www.umweltprobenbank.de/upb_static/fck/download/ SOP_Herring_gull.pdf].

57. Bignert A: PIA statistical application developed for use by the Arctic Monitoring and Assessment Programme.[http://www.amap.no].

58. Nicholson MD, Fryer R, Larsen JR: Temporal Trend Monitoring: Robust Method for Analysing Contaminant Trend Monitoring Data Copenhagen: ICES; 1998, Techniques in Marine Environmental Sciences, No 20.

59. Agency for Toxic Substances and Disease Registry: Toxicological profile for polychlorinated biphenyls (PCBs).[http://www.atsdr.cdc.gov/toxprofiles/ tp17.pdf].

60. Alcock RE, Boumphrey R, Malcom HM, Osborn D, Jones KC: Temporal and spatial trends of PCB congeners in UK gannet eggs. Ambio 2002, 31:202-206.

61. Fängström B, Athanasiadou M, Athanassiadis I, Bignert A, Grandjean P, Weihe P, Bergman $\AA$ : Polybrominated diphenyl ethers and traditional organochlorine pollutants in fulmars (Fulmarus glacialis) from the Faroe Islands. Chemosphere 2005, 60:836-43.

62. Braune BM: Temporal trends of organochlorines and mercury in seabird eggs from the Canadian Artic, 1975-2003. Environ Pollut 2007, 148:599-613.

63. Bignert A, Danielsson S, Strandmark A, Nyberg E, Asplund L, Eriksson U, Berger U, Wilander A, Haglund A: Comments concerning the National Swedish Contaminant Monitoring Programme in Marine Biota, 2008. [http://www.nrm.se/download/18.61d98c3a11a91af311a80001279/Marina +programmet+2008.pdf]

64. Helgason LB, Barrett R, Lie E, Polder A, Skaare JU, Gabrielsen GW: Levels and temporal trends (1983-2003) of persistent organic pollutants (POPs) and mercury $(\mathrm{Hg})$ in seabird eggs from northern Norway. Environ Pollut 2008, 155:190-198.

65. Jörundsdóttir $H$, Bignert $A$, Svavarsson J, Nygård T, Weihe $P$, Bergman A: Assessment of emerging and traditional halogenated contaminants in guillemot (Uria aalge) egg from North-Western Europe and the Baltic. SCl Tot Environ 2009, 407:4174-4183.

66. Pereira MG, Walker LA, Best J, Shore RF: Long-term trends in mercury and PCB congener concentrations in gannet (Morus bassanus) eggs in Britain. Environ Pollut 2009, 157:155-163.

67. Herzke D, Nygård T, Berger U, Huber S, Røv N: Perfluorinated and other persistent halogenated organic compounds in European shag (Phalacrocorax aristotelis) and common eider (Somateria mollissima) from Norway: a suburban to remote pollutant gradient. Sci Tot Environ 2009, 408:340-348.

68. Champoux L, Moisey J, Muir DCG: Polybrominated diphenyl ethers, toxaphenes, and other halogenated organic pollutants in great blue heron eggs. Environ Toxicol Chem 2010, 29:243-249.

69. Jörundsdóttir H, Löfstrand K, Svavarsson J, Bignert A, Bergman Å: Organochlorine compounds and their metabolites in seven Icelandic seabird species - a comparative study. Environ Sci Technol 2010, 44:3252-3259.

70. Bustnes JO, Helberg M, Strann KB, Skaare JU: Environmental pollutants in endangered vs. increasing subspecies of the lesser black-backed gull on the Norwegian coast. Environ Pollut 2006, 144:893-901.

71. Miljeteig C, Strøm H, Gavrilo MV, Volkov A, Jenssen BM, Gabrielsen GW: High levels of contaminants in ivory gull Pagophila eburnean eggs from the Russian and Norwegian Arctic. Environ Sci Technol 2009, 43:5521-5528.
72. Vorkamp K, Thomsen M, Møller S, Falk K, Sørensen PB: Persistent organochlorine compounds in peregrine falcon (Falco peregrinus) eggs from South Greenland: levels and temporal changes between 1986 and 2003. Environ Int 2009, 35:336-341.

73. Becker PH, Dittmann T: Contaminants in bird eggs. Thematic Report No. 5.2. In Quality Status Report 2009. Wadden Sea Ecosystem No. 25. Edited by: Marencic H, de Vlas J. Wilhelmshaven: Common Wadden Sea Secretariat, Trilateral Monitoring and Assessment Group; 2009:

74. Thyen S, Becker PH, Behmann H: Organochlorine and mercury concentration of little terns (Sterna albifrons) breeding at the western Baltic Sea, 1978-96. Environ Pollut 2000, 108:225-238.

75. Carlsson P, Herzke D, Wedborg M, Gabrielsen GW: Environmental pollutants in the Swedish marine ecosystem, with special emphasis on polybrominated diphenyl ethers (PBDE). Chemosphere 2011, 82:1286-1292.

76. OSPAR Commission: Background document on the EcoQO on mercury and organohalogens in seabird eggs.[http://www.ospar.org/documents/ dbase/publications/p00331_EcoQO-Birdeggs.pdf].

77. Mattig FR, Becker PH, Bietz H, Gießing K: Schadstoffanreicherung im Nahrungsnetz des Wattenmeeres.Forschungsbericht 108020 85/21. Berlin: Umweltbundesamt; 1996.

78. Fernie K, Bortolotti G, Smits J: Reproductive abnormalities, teratogenicity, and developmental problems in American kestrels (Falco sparverius) exposed to polychlorinated biphenyls. J Toxicol Environ Health A 2003, 66:2089-2103.

79. Ormerod SJ, Tyler SJ, Jüttner I: Effects of point-source PCB contamination on breeding performance and post-fledging survival in the dipper Cinclus cinclus. Environ Pollut 2000, 109:505-513.

80. Strause KD, Zwiernik MJ, Hyeon Im S, Bradley PW, Moseley PP, Kay DP, Park CS, Jones PD, Blankenship AL, Newsted JL, Giesy JP: Risk assessment of great horned owls (Bubo virginanus) exposed to polychlorinated biphenyls and DDT along the Kalamazoo River, Michigan, USA. Environ Toxicol Chem 26:1386-1398.

81. OECD Environment, Health and Safety Publication Series on Risk Management No. 21: Lists of PFOS, PFAS, PFOA, PFCA, Related Compounds and Chemicals that may Degrade to PFCA. ENV/JM/MONO (2006)15 as Revised 2007. [http://www.oecd.org/officialdocuments/ publicdisplaydocumentpdf/?cote=ENV/JM/MONO(2006) 15\&docLanguage $=E n]$.

82. OECD Environment, Health and Safety Publication Series on Risk Management No. 23: Report of an OECD Workshop on Perfuorocarboxylic Acids (PFCAs) and Precursors 2007. ENV/JM/MONO (2007)11. [http://www.oecd.org/officialdocuments/ publicdisplaydocumentpdf/?cote=ENV/JM/MONO(2007) $11 \&$ docLanguage $=$ En].

83. Verreault J, Berger U, Gabrielsen GW: Trends of perfluorinated alkyl substances in herring gull eggs from two coastal colonies in northern Norway: 1983-2003. Environ Sci Technol 2007, 41:6671-6677.

84. Löfstrand $K$, Jörundsdóttir H, Tomy G, Svavarsson J, Weihe P, Nygård T, Bergman A: Spatial trends of polyfluorinated compounds in guillemot (Uria aalge) eggs from North-Western Europe. Chemosphere 2008, 72:1475-1480.

85. Wang Y, Yeung LWY, Taniyasu S, Yamashita N, Lam JCW, Lam PKS: Perfluorinated sulfonates and other fluorochemicals in water bird eggs from south China. Environ Sci Technol 2008, 42:8146-8151.

86. Yoo H, Kannan K, Kim SK, Lee KT, Newsted JL, Giesy JP: Perfluoroalkyl acids in egg yolk of birds from Lake Shihwa, Korea. Environ Sci Technol 2008, 42:5821-5827.

87. Gebbink WA, Hebert CE, Letcher RJ: Perfluorinated carboxylates and sulfonates and precursor compounds in herring gull eggs from colonies spanning the Laurentian Great Lakes of North America. Environ Sci Technol 2009, 43:7443-7449.

88. Bignert A, Danielsson S, Nyberg E, Berger U: Perfluorooctane sulfonate (PFOS) concentrations in fish liver and guillemot egg. HELCOM Indicator Fact Sheets, http://www.helcom.fi/BSAP_assessment/ifs/en_GB/cover/]. Fact sheet of 2008: [http://www.helcom.fi/BSAP_assessment/ifs/archive/ifs2008/ en_GB/pfos/.

89. Newsted JL, Jones PD, Coady K, Giesy JP: Avian toxicity reference values for perfluorooctane sulfonate. Environ Sci Technol 2005, 39:9357-9362

90. Bustnes JO, Erikstad KE, Lorentsen SH, Herzke D: Perfluorinated and chlorinated pollutants as predictors of demographic parameters in an endangered seabird. Environ Pollut 2008, 156:417-424. 
91. La Guardia MJ, Hale RC, Harvey E: Detailed polybrominated diphenyl ether (PBDE) congener composition of the widely used Penta-, Octaand Deca-PBDE technical flame-retardant mixtures. Environ Sci Technol 2006, 40:6247-6254.

92. EU-JRC: Bis(pentabromophenyl)ether. European Union Risk Assessment Report Vol. 17. 2002.[http://esis.jrc.ec.europa.eu/doc/existing-chemicals/ risk_assessment/REPORT/decabromodiphenyletherreport013.pdf].

93. Sellström U, Bignert A, Kierkegaard A, Häggberg L, De Wit CA, Olsson M, Jansson B: Temporal trend studies on tetra- and pentabrominated diphenyl ethers and hexabromocyclododecane in guillemot eggs from the Baltic Sea. Environ Sci Technol 2003, 37:5496-5501.

94. Helgason LB, Polder A, Føreid S, Bæk K, Lie E, Gabrielsen GW, Barrett RT, Skaare JU: Levels and temporal trends (1983-2003) of polybrominated diphenyl ethers and hexabromocyclododecanes in seabird eggs from North Norway. Environ Toxicol Chem 2009, 28:1096-1103.

95. Elliot JE, Wilson LK, Wakeford B: Polybrominated diphenyl ether trends in eggs of marine and freshwater birds from British Columbia, Canada, 1979-2002. Environ Sci Technol 2005, 39:5584-5591.

96. Gauthier LT, Hebert CE, Chip Weseloh DV, Letcher RJ: Current-use flame retardants in eggs of herring gulls (Larus argentatus) from Laurentian Great Lakes. Environ Sci Technol 2007, 41:4561-4567.

97. Verreault J, Gebbink WA, Gauthier LT, Gabrielsen GW, Letcher RJ: Brominated flame retardants in glaucous gulls from the Norwegian Arctic: more than just an issue of polybrominated diphenyl ethers. Environ Sci Technol 2007, 41:4925-4931.

98. Fernie KJ, Shutt JL, Letcher RJ, Ritchie IJ, Sullivan K, Bird DM: Changes in reproductive courtship behaviour of adult American kestrels (Falco spavarius) exposed to environmentally relevant levels of the polybrominated diphenyl ether mixture, DE-71. Toxicol Sci 2008 , 102:171-178.

99. McKernan MA, Rattner BA, Hale RC, Ottinger MA: Toxicity of polybrominated diphenyl ethers (DE-71) in chicken (Gallus gallus), mallard (Anas playrhynchos), and American kestrel (Falco spaverius) embryos and hatchlings. Environ Tox Chem 2009, 28:1007-1017.

100. Eriksson P, Fischer C, Fredriksson A: Polybrominated diphenyl ethers, a group of brominated flame retardants, can interact with polychlorinated biphenyls in enhancing developmental neurobehavioral defects. Toxicol Sci 2006, 94:302-309.

101. 3M: 3 M's phase out and new technologies. [http://solutions.3m.com/wps/ portal/3M/en_US/PFOS/PFOA/Information/phase-out-technologies/].

doi:10.1186/2190-4715-24-7

Cite this article as: Fliedner et al: Levels and trends of industrial chemicals (PCBs, PFCs, PBDEs) in archived herring gull eggs from German coastal regions. Environmental Sciences Europe 2012 24:7.

\section{Submit your manuscript to a SpringerOpen ${ }^{\circ}$ journal and benefit from:}

- Convenient online submission

- Rigorous peer review

- Immediate publication on acceptance

- Open access: articles freely available online

- High visibility within the field

- Retaining the copyright to your article

Submit your next manuscript at $\gg$ springeropen.com 